\title{
PENERAPAN METODE TOPSIS SEBAGAI PENGUKURAN DALAM PENETAPAN KANDIDAT CALON PENERIMA KIP PADA PERGURUAN TINGGI SWASTA (PTS)
}

\author{
Eva Julia Gunawati Harianja \\ Progam Studi Manajemen Informatika \\ Universitas Methodist Indonesia \\ graziedamanik@gmail.com
}

\begin{abstract}
Education and teaching are the rights of every citizen as regulated in the 1945 Constitution which is written in article 31, paragraph (1). However, the high cost of education sometimes becomes an obstacle for economically disadvantaged people, so that many secondary graduates are unable to continue their education to higher education even though they have good academic potential. The government has tried to provide a solution to this problem by organizing the Smart Indonesia Program (PIP) in helping its citizens obtain the right to higher education, namely through the provision of KIP Lectures that can be submitted by students at PTN and PTS. Private universities which act as facilitators for students in submitting KIP Lecture applications are expected to be more selective in the candidate selection process so that the distribution of assistance is right on target. Determination of KIP Lecture recipients based on certain criteria is often a problem in the decision-making process. To express the preferences of decision makers on the most desirable alternative, it can be done by applying the Technique For Order Preference by Similarity to Ideal Solution (TOPSIS). The TOPSIS method will be combined with fuzzy logic to determine the weight value for each criterion attribute, followed by a ranking process to select the best alternative, in this case a valid alternative as a beneficiary that fits the criteria. With this method, it is hoped that the assessment process will be more precise and accurate because it is based on predetermined criteria and weights.
\end{abstract}

Keywords: education, pts, kip, fuzzy, topsis

\section{PENDAhuluan}

Perguruan Tinggi merupakan satuan pendidikan yang menyelenggarakan pendidikan tinggi, yang dapat berbentuk akademi, politeknik, sekolah tinggi, institut, atau universitas. Berdasarkan kepemilikannya, Perguruan Tinggi dibagi menjadi dua yaitu Perguruan Tinggi Negeri (PTN) dan Perguruan Tinggi Swasta (PTS). Perguruan Tinggi Swasta (PTS) dikelola oleh masyarakat sesuai dengan perundang-undangan yang berlaku, yang penyelenggaraannya di awasi oleh suatu lembaga Koordinasi Perguruan Tinggi Swasta yang disebut Kopertis (Wikipedia). Dalam penyelenggaraanya keberadaan PTS selalu menjadi pilihan kedua bagi calon mahasiswa karena biaya pendidikan yang dianggap cukup mahal bila dibandingkan dengan biaya pendidikan di Perguruan Tinggi Negeri (PTN). Untuk itu PTS harus berusaha untuk memberikan kemudahan bagi mahasiswa dalam hal biaya kuliah dengan menyediakan berbagai program bantuan uang kuliah yang salah satunya adalah program KIP Kuliah. Karena saat ini masih banyak PTS yang belum menyelenggarakan program bantuan berupa KIP Kuliah ini. Sama halnya dengan PTN Diharapkan PTS juga mengadakan program KIP Kuliah ini, Setidaknya PTS dapat menjadi fasilitator bagi mahasiswa dalam mendapatkan bantuan biaya pendidikan dari Pemerintah melalui KIP Kuliah. Karena dalam pengajuan bantuan KIP Kuliah ini dapat dilakukan dengan dua cara, yang salah satunya adalah Perguruan Tinggi dapat mendaftarkan mahasiswa yang sudah diterima dan melakukan registrasi. Oleh karena begitu banyaknya mahasiswa kurang mampu secara ekonomi yang ingin mendapatkan bantuan dana pendidikan tersebut dan mengajukan permohonan penerimaan KIP Kuliah, maka pemerintah maupun pihak terkait yang menyelenggarakan program tersebut, diharapkan lebih selektif dalam memilih penerima KIP berdasarkan kriteria ataupun syarat tertentu. Khususnya PTS sebagai fasilitator dapat melakukan seleksi terhadap kandidat calon penerima bantuan KIP Kuliah, agar bantuan pendidikan tersebut benar-benar sampai kepada orang yang tepat. Metode yang dipakai dalam sistem pendukung keputusan penerimaan KIP Kuliah adalah Technique For Order Preference by Similarity to Ideal Solution (TOPSIS)[1]. Metode TOPSIS dipilih karena metode TOPSIS merupakan suatu bentuk metode pendukung keputusan yang didasarkan pada konsep bahwa alternatif yang terbaik tidak hanya memiliki jarak terpendek dari solusi ideal positif tetapi juga memiliki jarak terpanjang dari solusi ideal negatif yang dalam hal ini akan memberikan rekomendasi calon penerima KIP yang sesuai dengan yang diharapkan. Untuk membantu proses pengambilan keputusan dalam Penetapan Kandidat Calon Penerima KIP Pada Perguruan Tinggi Swasta dalam penelitian ini dapat digunakan metode TOPSIS. Tujuan penelitian ini adalah membantu Perguruan Tinggi Swasta (PTS) dalam memilih para 
kandidat yang akan diajukan sebagai calon penerima bantuan KIP yang diselenggarakan oleh pemerintah melalui Pusat Layanan Pendidikan (Puslapdik) Kementrian Pendidikan dan Kebudayaan (Kemendikbud) dengan menggunakan metode TOPSIS. Diharapkan dengan menggunakan metode ini diharapkan proses penentuan kandidat calon penerima bantuan KIP pada Perguruan Tinggi Swasta (PTS) dapat dilakukan dengan baik, sehingga diperoleh kandidat yang tepat sesuai dengan kriteria yang dimilikinya.

\section{TINJAUAN PUSTAKA}

\section{Kartu Indonesia Pintar}

Kartu Indonesia Pintar (KIP) suatu bentuk bantuan pemerintah dalam membantu warganya memperoleh hak pendidikan tinggi. KIP Kuliah akan menjamin keberlangsungan kuliah dengan memberikan pembebasan biaya kuliah di perguruan tinggi dan bantuan biaya hidup bulanan bagi mahasiswa yang memenuhi persyaratan ekonomi dan akademik.

Berdasarkan UU No 12/2012 tentang Pendidikan Tinggi, Pemerintah Indonesia berkewajiban meningkatkan akses dan kesempatan belajar di Perguruan Tinggi serta menyiapkan insan Indonesia yang cerdas dan kompetitif. Oleh karena itu Pemerintah akan selalu berupaya untuk menjamin, bahwa anak Indonesia yang kurang mampu terutama yang memiliki prestasi akan dapat terus menempuh pendidikan hingga jenjang kuliah melalui Program Indonesia Pintar (PIP)[6].

Permendikbud No 10 Tahun 2020 tentang Program Indonesia Pintar, PIP diperuntukkan bagi mahasiswa yang diterima di Perguruan Tinggi termasuk penyandang disabilitas dengan prioritas sasaran mahasiswa pemegang KIP, mahasiswa dari keluarga miskin/rentan miskin dan/atau dengan pertimbangan khusus, mahasiswa afirmasi (Papua dan Papua Barat serta 3T dan TKI) serta mahasiswa terkena bencana, konflik sosial atau kondisi khusus. Pemerintah melalui Puslapdik Kemendikbud kembali akan menyalurkan bantuan untuk melanjutkan pendidikan tinggi kepada 200 ribu mahasiswa penerima KIP Kuliah baru, selain terus menjamin penyaluran KIP Kuliah on going dan Bidikmisi on going sampai masa studi selesai.[4][7]

\section{Technique For Order Preference by Similarity to Ideal Solution (TOPSIS)}

TOPSIS merupakan salah satu metode yang dapat digunakan untuk mengatasi permasalahan multikriteria, yang memberikan sebuah solusi dari sejumlah alternatif yang mungkin dengan cara membandingkan setiap alternatif dengan alternatif terbaik dan alternatif terburuk yang ada diantara alternatif-alternatif masalah. Metode ini menggunakan jarak untuk melakukan perbandingan tersebut. TOPSIS diperkenalkan pertama kali oleh Yoon dan Hwang pada tahun 1981[8][9], mereka mengembangkan metode TOPSIS berdasarkan intuisi yaitu alternatif pilihan merupakan alternatif yang mempunyai jarak terkecil dari solusi ideal positif dan jarak terbesar dari solusi ideal negatif dari sudut pandang geometris dengan menggunakan jarak Euclidean[9].

Ada beberapa langkah penyelesaian yang harus diperhatikan dalam metode TOPSIS[1] antara lain:

1. Membuat matriks keputusan yang ternormalisasi

2. Membuat matriks keputusan yang ternormalisasi terbobot

3. Menentukan matriks solusi ideal positif dan solusi ideal negatif

4. Menghitung separation measure

5. Menentukan jarak antara nilai setiap alternative dengan matriks solusi ideal positif dan negative

6. Menentukan nilai preferensi untuk setiap alternative

\section{Logika Fuzzy}

Logika fuzzy pertama kali diperkenalkan oleh Lotfi A. Zadeh. Teori fuzzy memiliki derajat keanggotaan dalam rentang 0(nol) hingga 1(satu), berbeda dengan logika digital yang hanya memiliki dua nilai yaitu 1 (satu) atau 0 (nol). Logika fuzzy digunakan untuk menerjemahkan suatu besaran yang diekspresikan menggunakan bahasa (linguistic), misalkan besaran kecepatan laju kendaraan yang diekspresikan dengan pelan, agak cepat, cepat dan sangat cepat[3].

Himpunan fuzzy didasarkan pada gagasan untuk memperluas jangkauan fungsi karakteristik sedemikian hingga fungsi tersebut akan mencakup bilangan real pada interval $[0,1]$. Nilai keanggotaannya menunjukkan bahwa suatu item tidak hanya bernilai benar atau salah. Nilai 0 menunjukkan salah, nilai 1 menunjukkan benar, dan masih ada nilai-nilai yang terletak antara benar dan salah. Jika $X$ adalah suatu kumpulan obyek-obyek dan $x$ adalah elemen dari $X$. Maka himpunan fuzzy $A$ yang memiliki domain $X$ didefinisikan sebagai:

$$
A=\left\{\left(x, \mu_{A}(x)\right) \mid x \in X\right\}
$$

dimana nilai $\mu_{A}(x)$ berada dalam rentang 0 hingga 1.

Fungsi-fungsi keanggotaan fuzzy yang umum digunakan diantaranya adalah: Fungsi keanggotaan segitiga, disifati oleh parameter $\{a, b, c\}$ yang didefinisikan sebagai berikut:

$$
\operatorname{segitig} a(x ; a, b, c)=\left\{\begin{array}{cl}
0, & x \leq a \\
\frac{x-a}{b-a}, & a \leq x \leq b \\
\frac{c-x}{c-b}, & b \leq x \leq c \\
0, & \mathrm{c} \leq \mathrm{x}
\end{array}\right.
$$

bentuk yang lain dari persamaan di atas adalah 
$\operatorname{segitig} a(x ; a, b, c)=\max \left(\min \left(\frac{x-a}{b-a}, \frac{c-x}{c-b}\right), 0\right)$

parameter $\{a, b, c\}$ (dengan $a<b<c$ ) yang menentukan koordinat $x$ dari ketiga sudut segitiga tersebut.

\section{METODE ANALISIS}

Pada penerimaan KIP kuliah yang yang diselenggarakan oleh pemerintah melalui Kementrian Pendidikan dan Kebudayaan (Kemendikbud) terdapat beberapa persyaratan yang harus di penuhi oleh calon penerima atau mahasiswa, yang pada dasarnya calon penerima KIP Kuliah ini haruslah memiliki Potensi Akademik yang baik serta memiliki keterbatasan ekonomi. Untuk itu, dalam penentuan penerima bantuan KIP pada Perguruan Tinggi Swata (PTS) yang dibahas dalam penelitian ini diperlukan beberapa kriteria untuk pengambilan keputusan. Adapun kriteria yang merupakan syarat dalam penentuan penentuan penerima bantuan KIP yang ditetapkan oleh pemerintah melalui Kementrian Pendidikan dan Kebudayaan (Kemendikbud) yaitu Nilai Akadmeik (C1), Kondisi Atap Rumah (C2), Kondisi Dinding Rumah (C3), Kondisi Lantai Rumah (C4), Kondisi MCK (C5), Kepemilikan Rumah (C6), Jumlah Gabungan Penghasilan Orang Tua (C7) dan Jumlah Saudara Kandung (C8) dengan bobot tingkat kepentingan kriteria berdasarkan bilangan fuzzy, ditampilkan pada gambar 1 yaitu: Kurang Penting $(K P)=0$, Penting $(P)=0,5$ dan Sangat Penting $(\mathrm{SP})=1$.

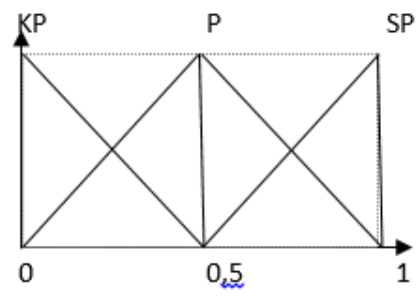

Gambar 1. Skala Bobot

Keterangan:

$\begin{array}{ll}\mathrm{KP} & =\text { Kurang Penting } \\ \mathrm{P} & =\text { Penting } \\ \mathrm{SP} & =\text { Sangat Penting }\end{array}$

Dalam proses pengambilan keputusan pemilihan kandidat penerima bantuan KIP pada Perguruan Tinggi Swasta (PTS) yang dibahas dalam penelitian ini akan dibuat tabel nilai akhir yang menjadi acuan bagi untuk menentukan kandidat yang layak menerima bantuan KIP sesuai kriteria yang telah ditetapkan sebagai syarat penentuan penerima bantuan KIP. Data nilai akhir akan ditampilkan pada tabel 1 berikut:

Tabel 1. Tabel Nilai Akhir

\begin{tabular}{|c|c|}
\hline Nilai Akhir & Predikat \\
\hline$>0,5$ & Rekomendasi \\
\hline $0,1<\mathrm{NA} \leq 0,5$ & Tidak Rekomendasi \\
\hline
\end{tabular}

Tabel Bobot Kriteria

Berdasarkan kriteria dan rating kecocokan setiap alternatif pada kriteria yang telah ditetapkan sebelumnya, maka penjabaran bobot setiap kriteria yang telah dikonversikan dengan bilangan fuzzy akan ditampilkan pada tabel-tabel berikut:

\section{Nilai Akademik}

Tabel 2. Tabel Bobot Kriteria Nilai Akademik

\begin{tabular}{|c|c|}
\hline Nilai Akademik (C1) & Nilai \\
\hline$>3.50$ & 1 \\
\hline $2.75<\mathrm{x} \leq 3.50$ & 0,5 \\
\hline$\leq 2.75$ & 0 \\
\hline
\end{tabular}

Kriteria Atap Rumah

Tabel 3. Tabel Bobot Kriteria Atap Rumah

\begin{tabular}{|c|c|}
\hline Atap Rumah (C2 ) & Nilai \\
\hline Rumbia & 1 \\
\hline Seng & 0,5 \\
\hline Genteng & 0 \\
\hline
\end{tabular}

\section{Kriteria Dinding Rumah}

Tabel 4. Tabel Bobot Kriteria Dinding Rumah

\begin{tabular}{|c|c|}
\hline Dinding Rumah $(\mathbf{C 3})$ & Nilai \\
\hline Papan/Anyaman bambu & 1 \\
\hline Plesteran anyaman bambu & 0,5 \\
\hline Tembok Plesteran & 0 \\
\hline
\end{tabular}

\section{Kriteria Lantai Rumah}

Tabel 5. Tabel Bobot Kriteria Lantai Rumah

\begin{tabular}{|c|c|}
\hline Lantai Rumah $(\mathbf{C 4})$ & Nilai \\
\hline Tanah & 1 \\
\hline Plester & 0,5 \\
\hline Tegel & 0 \\
\hline
\end{tabular}

\section{Kriteria MCK}

Tabel 6. Tabel Bobot Kriteria MCK

\begin{tabular}{|c|c|}
\hline Kondisi MCK (C5 ) & Nilai \\
\hline Terpisah/diluar rumah & 1 \\
\hline Didalam rumah & 0,5 \\
\hline
\end{tabular}

\section{Kriteria Kepemilikan Rumah}

Tabel 7. Tabel Bobot Kriteria Kepemilikan Rumah

\begin{tabular}{|c|c|}
\hline Kondisi Kepemilikan (C6 ) & Nilai \\
\hline Kontrak/Sewa & 1 \\
\hline Bukan Hak Milik & 0,5 \\
\hline Hak Milik & 0 \\
\hline
\end{tabular}




\section{Kriteria Penghasilan Orang Tua}

Tabel 8. Tabel Bobot Kriteria Penghasilan

\begin{tabular}{|c|c|}
\hline Penghasilan (C7) & Nilai \\
\hline$<=4$ Juta & 1 \\
\hline$>4$ Juta & 0 \\
\hline
\end{tabular}

\section{Kriteria Jumlah Saudara}

Tabel 9. Tabel Bobot Kriteria Jlh. Saudara

\begin{tabular}{|c|c|}
\hline Jumlah Saudara $($ C8 $)$ & Nilai \\
\hline$>=3$ & 1 \\
\hline 2 & 0,5 \\
\hline 1 & 0 \\
\hline
\end{tabular}

IV. HASIL DAN PEMBAHASAN

Dalam pembahasan tentang penentuan pemilihan kandidat penerima bantuan KIP pada Perguruan Tinggi Swasta (PTS) menggunakan Technique For Order Preference by Similarity to Ideal Solution (TOPSIS) menggunakan kasus sebagai berikut:

Tabel 10. Data Mahasiswa Sebagai Kandidat Calon Penerima Bantuan KIP

\begin{tabular}{|l|r|l|l|l|l|l|r|r|}
\hline CALON & AKADEMIK & \multicolumn{1}{|c|}{ ATAP } & DINDING & LANTAI & \multicolumn{1}{c|}{ MCK } & KEPEMILIKAN & PENGHASILAN & SAUDARA \\
\hline MHS1 & 2,75 & RUMBIAH & PAPAN & TANAH & TERPISAH & HAK MILIK & 2000000 & 2 \\
\hline MHS2 & 2,75 & RUMBIAH & $\begin{array}{l}\text { SEMI } \\
\text { PLESTERAN }\end{array}$ & TANAH & TERPISAH & HAK MLLIK & 3000000 & 1 \\
\hline MHS3 & 3,50 & SENG & TEMBOK & PLESTER & DIDALAM & $\begin{array}{l}\text { BUKAN HAK } \\
\text { MLLIK }\end{array}$ & 4000000 & 2 \\
\hline MHS4 & 3,60 & GENTENG & TEMBOK & TEGEL & DIDALAM & KONTRAK & 5000000 & 4 \\
\hline MHS3 & 3,70 & SENG & PAPAN & PLESTER & DIDALAM & $\begin{array}{l}\text { BUKAN HAK } \\
\text { MLLIK }\end{array}$ & 3500000 & 3 \\
\hline MHS6 & 3,48 & SENG & $\begin{array}{l}\text { SEMI } \\
\text { PLESTERAN }\end{array}$ & TANAH & TERPISAH & HAK MILIK & 3000000 & 2 \\
\hline MHS7 & 3,00 & SENG & TEMBOK & PLESTER & DIDALAM & KONTRAK & 4000000 & 3 \\
\hline MHS8 & 3,58 & GENTENG & TEMBOK & TEGEL & DIDALAM & HAK MILIK & 5000000 & 2 \\
\hline MHS9 & 2,90 & SENG & $\begin{array}{l}\text { SEMI } \\
\text { PLESTERAN }\end{array}$ & PLESTER & DIDALAM & KONTRAK & 3800000 & 3 \\
\hline MHS10 & 3,84 & SENG & TEMBOK & PLESTER & DIDALAM & KONTRAK & 4000000 & 2 \\
\hline
\end{tabular}

Berdasarkan data yang diperoleh, maka untuk mengetahui mahasiswa penerima bantuan KIP yang akan di tetapkan sebagai kandidat tersebut perlu dibuat format preferensi yang ditransformasikan dalam bentuk bilangan fuzzy sebagai berikut:

Tabel 11. Tabel Kecocokan Setiap Alternatif

\begin{tabular}{|l|r|r|r|r|r|r|r|r|}
\hline & \multicolumn{1}{|c|}{ C1 } & \multicolumn{1}{c|}{ C2 } & \multicolumn{1}{c|}{ C3 } & C4 & C5 & C6 & C7 & C8 \\
\hline $\mathbf{A 1}$ & 0 & 1 & 1 & 1 & 1 & 0 & 1 & 0,5 \\
\hline $\mathbf{A 2}$ & 0 & 1 & 0,5 & 1 & 1 & 0 & 1 & 0 \\
\hline $\mathbf{A 3}$ & 0,5 & 0,5 & 0 & 1 & 0 & 0,5 & 1 & 0,5 \\
\hline $\mathbf{A 4}$ & 1 & 0 & 0 & 0 & 0 & 1 & 0 & 1 \\
\hline $\mathbf{A 5}$ & 1 & 0,5 & 1 & 1 & 0 & 0,5 & 1 & 1 \\
\hline $\mathbf{A 6}$ & 0,5 & 0,5 & 0,5 & 1 & 1 & 0 & 1 & 0,5 \\
\hline $\mathbf{A 7}$ & 0,5 & 0,5 & 0 & 1 & 0 & 1 & 1 & 1 \\
\hline $\mathbf{A 8}$ & 1 & 0 & 0 & 0 & 0 & 0 & 0 & 0,5 \\
\hline $\mathbf{A 9}$ & 0,5 & 0,5 & 0,5 & 1 & 0 & 1 & 1 & 1 \\
\hline $\mathbf{A 1 0}$ & 1 & 0,5 & 0 & 1 & 0 & 1 & 1 & 0,5 \\
\hline
\end{tabular}

\section{a. Penentuan normalisasi matriks keputusan}

Dengan menggunakan rumus

$$
r_{i j}=\frac{x_{i j}}{\sqrt{\sum_{i=1}^{m} x_{i j}}}
$$

$\mathrm{X}(\mathrm{i})$ dimana $\mathrm{i}=1,2,3,4,5$ dan 6

dengan $i=1,2, \ldots, m$ dan $j=1,2, \ldots, n$

$\mathrm{X} 1=$

$\sqrt{0^{2}+0^{2}+0,5^{2}+1^{2}+1^{2}+0,5^{2}+0,5^{2}+1^{2}+0,5^{2}+1^{2}}=$ 2,2360680

$$
\begin{aligned}
& \mathrm{R}_{1.1}=\frac{0}{2,2360680}=0 \\
& \mathrm{R}_{2.1}=\frac{0}{2,2360680}=0 \\
& \mathrm{R}_{3.1}=\frac{0,5}{2,2360680}=0,2236068 \\
& \mathrm{R}_{4.1}=\frac{1}{2,2360680}=0,4472136 \\
& \mathrm{R}_{5.1}=\frac{1}{2,2360680}=0,4472136 \\
& \mathrm{R}_{6.1}=\frac{0,5}{2,2360680}=0,2236068 \\
& \mathrm{R}_{7.1}=\frac{0,5}{2,2360680}=0,2236068 \\
& \mathrm{R}_{8.1}=\frac{1}{2,2360680}=0,4472136 \\
& \mathrm{R}_{9.1}=\frac{0,5}{2,2360680}=0,2236068 \\
& \mathrm{R}_{10.1}=\frac{1}{2,2360680}=0,4472136
\end{aligned}
$$

$\mathrm{X} 2=$

$\sqrt{1^{2}+1^{2}+0,5^{2}+0^{2}+0,5^{2}+0,5^{2}+0,5^{2}+0^{2}+0,5^{2}+0,5^{2}}$ $=1,8708287$

$\mathrm{X} 3=$

$\sqrt{1^{2}+0,5^{2}+0^{2}+0^{2}+1^{2}+0,5^{2}+0^{2}+0^{2}+0,5^{2}+0^{2}}$ $=1,6583124$

$X 4=\sqrt{1^{2}+1^{2}+1^{2}+0^{2}+1^{2}+1^{2}+1^{2}+0^{2}+1^{2}+1^{2}}$

$=2,8284271$

$X 5=\sqrt{1^{2}+1^{2}+0^{2}+0^{2}+0^{2}+1^{2}+0^{2}+0^{2}+0^{2}+0^{2}}$

$=1,7320508$ 
$X 6=\sqrt{0^{2}+0^{2}+0,5^{2}+1^{2}+0,5^{2}+0^{2}+1^{2}+0^{2}+1^{2}+1^{2}}$ $=2,1213203$

$X 7=\sqrt{1^{2}+1^{2}+1^{2}+0^{2}+1^{2}+1^{2}+1^{2}+0^{2}+1^{2}+1^{2}}$

$=2,8284271$

$X 7=\sqrt{1^{2}+1^{2}+1^{2}+0^{2}+1^{2}+1^{2}+1^{2}+0^{2}+1^{2}+1^{2}}$

$=2,8284271$

$\mathrm{X} 8=$

$\sqrt{0,5^{2}+0^{2}+0,5^{2}+1^{2}+1^{2}+0,5^{2}+1^{2}+0,5^{2}+1^{2}+0,5^{2}}$

$=2,2912878$

Berdasarkan perhitungan yang dilakukan pada tiap-tiap elemen bilangan fuzzy sesuai dengan rumus yang ditentukan, sehingga diperoleh matriks ternormalisasi seperti pada tabel 12 berikut:

Tabel 12. Tabel Matriks Ternormalisasi

\begin{tabular}{|l|c|c|c|c|c|c|c|c|}
\hline & $\mathbf{R i}, \mathbf{1}$ & $\mathbf{R i}, \mathbf{2}$ & $\mathbf{R i}, \mathbf{3}$ & $\mathbf{R i , 4}$ & $\mathbf{R i , 5}$ & $\mathbf{R i}, \mathbf{6}$ & $\mathbf{R i}, 7$ & $\mathbf{R i}, \mathbf{8}$ \\
\hline $\mathbf{A 1}$ & 0 & 0,53452248 & 0,6030227 & 0,3535534 & 0,5773503 & 0 & 0,3535534 & 0,2182179 \\
\hline $\mathbf{A 2}$ & 0 & 0,53452248 & 0,3015113 & 0,3535534 & 0,5773503 & 0 & 0,3535534 & 0 \\
\hline $\mathbf{A 3}$ & 0,2236068 & 0,26726124 & 0 & 0,3535534 & 0 & 0,2357023 & 0,3535534 & 0,2182179 \\
\hline $\mathbf{A 4}$ & 0,4472136 & 0 & 0 & 0 & 0 & 0,4714045 & 0 & 0,4364358 \\
\hline $\mathbf{A 5}$ & 0,4472136 & 0,26726124 & 0,6030227 & 0,35355339 & 0 & 0,2357023 & 0,3535534 & 0,4364358 \\
\hline $\mathbf{A 6}$ & 0,2236068 & 0,26726124 & 0,3015113 & 0,35355339 & 0,5773503 & 0 & 0,3535534 & 0,2182179 \\
\hline $\mathbf{A 7}$ & 0,2236068 & 0,26726124 & 0 & 0,35355339 & 0 & 0,4714045 & 0,3535534 & 0,4364358 \\
\hline $\mathbf{A 8}$ & 0,4472136 & 0 & 0 & 0 & 0 & 0 & 0 & 0,2182179 \\
\hline $\mathbf{A 9}$ & 0,2236068 & 0,26726124 & 0,3015113 & 0,35355339 & 0 & 0,4714045 & 0,3535534 & 0,4364358 \\
\hline $\mathbf{A 1 0}$ & 0,4472136 & 0,26726124 & 0 & 0,35355339 & 0 & 0,4714045 & 0,3535534 & 0,2182179 \\
\hline
\end{tabular}

\section{b. Menentukan matriks keputusan normalisasi} terbobot.

Dengan menggunakan rumus $V_{i j}=W_{j} r_{i j} V_{i j}(5)$

dengan $i=1,2,3, \ldots$, m;dan $j=1,2,3, \ldots, n$;

dan $W_{j}$ adalah bobot referensi dari setiap kriteria.

Dimana nilai bobot dari setiap kriteria sudah ditentukan sebelumnya sebagai berikut:

Tabel 13. Tabel Bobot Kriteria

\begin{tabular}{|l|c|}
\hline \multicolumn{1}{|c|}{ Kriteria } & Bobot \\
\hline Nilai Akademik & 1 \\
\hline Kondisi Atap & 0,5 \\
\hline Kondisi Dinding & 0,5 \\
\hline Kondisi Lantai & 0,5 \\
\hline MCK & 1 \\
\hline Kepemilikan Rumah & 1 \\
\hline Penghasilan & 1 \\
\hline Jumlah Saudara & 1 \\
\hline
\end{tabular}

Tabel 14. Tabel Matriks Keputusan Ternormalisasi

Terbobot

\begin{tabular}{|l|c|c|c|c|c|c|c|c|}
\hline & $\mathbf{V}(\mathbf{i}, \mathbf{1})$ & $\mathbf{V}(\mathbf{i}, \mathbf{2})$ & $\mathbf{V}(\mathbf{i}, \mathbf{3})$ & $\mathbf{V}(\mathbf{i}, \mathbf{4})$ & $\mathbf{V}(\mathbf{i}, \mathbf{5})$ & $\mathbf{V}(\mathbf{i}, \mathbf{6})$ & $\mathbf{V}(\mathbf{i}, \mathbf{7})$ & $\mathbf{V}(\mathbf{i}, \mathbf{8})$ \\
\hline $\mathbf{A 1}$ & 0 & 0,2672612 & 0,3015113 & 0,1767767 & 0,5773503 & 0 & 0,3535534 & 0,2182179 \\
\hline $\mathbf{A 2}$ & 0 & 0,2672612 & 0,1507557 & 0,1767767 & 0,5773503 & 0 & 0,3535534 & 0 \\
\hline $\mathbf{A 3}$ & 0,2236068 & 0,1336306 & 0 & 0,1767767 & 0 & 0,2357023 & 0,3535534 & 0,2182179 \\
\hline $\mathbf{A 4}$ & 0,4472136 & 0 & 0 & 0 & 0 & 0,4714045 & 0 & 0,4364358 \\
\hline $\mathbf{A 5}$ & 0,4472136 & 0,1336306 & 0,3015113 & 0,1767767 & 0 & 0,2357023 & 0,3535534 & 0,4364358 \\
\hline $\mathbf{A 6}$ & 0,2236068 & 0,1336306 & 0,1507557 & 0,1767767 & 0,5773503 & 0 & 0,3535534 & 0,2182179 \\
\hline $\mathbf{A 7}$ & 0,2236068 & 0,1336306 & 0 & 0,1767767 & 0 & 0,47140452 & 0,3535534 & 0,4364358 \\
\hline $\mathbf{A 8}$ & 0,4472136 & 0 & 0 & 0 & 0 & 0 & 0 & 0,2182179 \\
\hline $\mathbf{A 9}$ & 0,2236068 & 0,1336306 & 0,1507557 & 0,1767767 & 0 & 0,47140452 & 0,3535534 & 0,4364358 \\
\hline $\mathbf{A 1 0}$ & 0,4472136 & 0,1336306 & 0 & 0,1767767 & 0 & 0,47140452 & 0,3535534 & 0,2182179 \\
\hline
\end{tabular}

\section{c. Menentukan matriks solusi ideal positif dan} negatif

Dengan menggunakan rumus

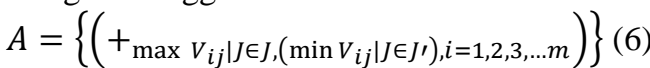

$$
\begin{aligned}
& ='\left\{v_{1}+v_{2}+v_{n^{+}}\right\}
\end{aligned}
$$

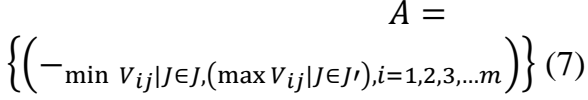

$$
\begin{aligned}
& ='\left\{v_{1^{-}}, v_{2^{-}}, v_{n^{-}}\right\}
\end{aligned}
$$

Tabel 15. Tabel Solusi Ideal Positif dan Negatif

\begin{tabular}{|l|c|c|c|c|c|c|c|c|}
\hline & $\mathbf{V}(\mathbf{i}, \mathbf{1})$ & $\mathbf{V}(\mathbf{i}, \mathbf{2})$ & $\mathbf{V}(\mathbf{i}, \mathbf{3})$ & $\mathbf{V}(\mathbf{i}, \mathbf{4})$ & $\mathbf{V}(\mathbf{i}, \mathbf{5})$ & $\mathbf{V}(\mathbf{i}, \mathbf{6})$ & $\mathbf{V}(\mathbf{i}, \mathbf{7})$ & $\mathbf{V}(\mathbf{i}, \mathbf{8})$ \\
\hline $\mathbf{A 1}$ & 0 & 0,2672612 & 0,3015113 & 0,1767767 & 0,5773503 & 0 & 0,3535534 & 0,2182179 \\
\hline $\mathbf{A} \mathbf{2}$ & 0 & 0,2672612 & 0,1507557 & 0,1767767 & 0,5773503 & 0 & 0,3535534 & 0 \\
\hline $\mathbf{A 3}$ & 0,2236068 & 0,1336306 & 0 & 0,1767767 & 0 & 0,2357023 & 0,3535534 & 0,2182179 \\
\hline $\mathbf{A 4}$ & 0,4472136 & 0 & 0 & 0 & 0 & 0,4714045 & 0 & 0,4364358 \\
\hline $\mathbf{A 5}$ & 0,4472136 & 0,1336306 & 0,3015113 & 0,1767767 & 0 & 0,2357023 & 0,3535534 & 0,4364358 \\
\hline $\mathbf{A} \mathbf{6}$ & 0,2236068 & 0,1336306 & 0,1507557 & 0,1767767 & 0,5773503 & 0 & 0,3535534 & 0,2182179 \\
\hline $\mathbf{A 7}$ & 0,2236068 & 0,1336306 & 0 & 0,1767767 & 0 & 0,47140452 & 0,3535534 & 0,4364358 \\
\hline $\mathbf{A 8}$ & 0,4472136 & 0 & 0 & 0 & 0 & 0 & 0 & 0,2182179 \\
\hline $\mathbf{A 9}$ & 0,2236068 & 0,1336306 & 0,1507557 & 0,1767767 & 0 & 0,47140452 & 0,3535534 & 0,4364358 \\
\hline $\mathbf{A 1 0}$ & 0,4472136 & 0,1336306 & 0 & 0,1767767 & 0 & 0,47140452 & 0,3535534 & 0,2182179 \\
\hline $\mathbf{A}+(\mathbf{V}$ MAX) & $\mathbf{0 , 4 4 7 2 1 3 6}$ & $\mathbf{0 , 2 6 7 2 6 1 2}$ & $\mathbf{0 , 3 0 1 5 1 1 3}$ & $\mathbf{0 , 1 7 6 7 7 6 7}$ & $\mathbf{0 , 5 7 7 3 5 0 3}$ & $\mathbf{0 , 4 7 1 4 0 4 5}$ & $\mathbf{0 , 3 5 3 5 5 3 4}$ & $\mathbf{0 , 4 3 6 4 3 5 8}$ \\
\hline $\mathbf{A}$-(V MIN) & $\mathbf{0}$ & $\mathbf{0}$ & $\mathbf{0}$ & $\mathbf{0}$ & $\mathbf{0}$ & $\mathbf{0}$ & $\mathbf{0}$ & $\mathbf{0}$ \\
\hline
\end{tabular}

d. Menghitung separation measure

solusi ideal positif $\left(S^{+}\right)$dengan menggunakan

rumus $S_{i}^{+}=\sqrt{\sum_{j=1}^{n}\left(V_{i j}-V_{j}^{+}\right)^{2}}$

dari solusi ideal negatif $\left(S^{-}\right)$menggunakan rumus

$$
S_{i}^{-}=\sqrt{\sum_{j=1}^{n}\left(V_{i j}-V_{j}^{-}\right)^{2}}
$$

hasil perhitungan didapat seperasi (jarak) solusi ideal positif dan jarak solusi ideal negatif seperti pada tabel 16 berikut :

Tabel 16. Tabel Nilai Seperasi (Jarak)

\begin{tabular}{|c|c|}
\hline S+ & S- \\
\hline 0,6854497 & 0,836385 \\
\hline 0,7971359 & 0,764028 \\
\hline 0,7715401 & 0,572085 \\
\hline
\end{tabular}




\begin{tabular}{|l|l|}
\hline 0,8074162 & 0,782751 \\
\hline 0,6377664 & 0,843237 \\
\hline 0,6003546 & 0,792330 \\
\hline 0,7014981 & 0,798001 \\
\hline 0,9600845 & 0,497613 \\
\hline 0,6510897 & 0,812116 \\
\hline 0,6997990 & 0,802464 \\
\hline
\end{tabular}

\section{e. Hitung kedekatan relatif dari setiap alternatif terhadap solusi ideal positif (ci+)}

Dengan menggunakan rumus

$$
\begin{aligned}
& c_{j}^{+}=\frac{s_{i}^{-}}{s_{i}^{-}+S_{i}^{+}} \\
& \quad \text { dengan } \mathrm{i}=1,2,3, \ldots, \mathrm{m}
\end{aligned}
$$

Tabel 17. Tabel Kedekatan Relatif

\begin{tabular}{|c|c|c|}
\hline S+ & S- & C+ \\
\hline 0,6854497 & 0,836385 & 0,5495899 \\
\hline 0,7971359 & 0,764028 & 0,4893965 \\
\hline 0,7715401 & 0,572085 & 0,4257774 \\
\hline 0,8074162 & 0,782751 & 0,4922443 \\
\hline 0,6377664 & 0,843237 & 0,5693686 \\
\hline 0,6003546 & 0,792330 & 0,5689228 \\
\hline 0,7014981 & 0,798001 & 0,5321784 \\
\hline 0,9600845 & 0,497613 & 0,3413693 \\
\hline 0,6510897 & 0,812116 & 0,5550253 \\
\hline 0,6997990 & 0,802464 & 0,5341701 \\
\hline
\end{tabular}

\section{f. Perangkingan alternatif}

Proses perangkingan terhadap alternatif dilakukan dengan tujuan untuk memperoleh nilai tertinggi dari bobot kriteria yang telah di tentukan.

Tabel 18. Tabel Hasil Proses Perangkingan

\begin{tabular}{|c|c|c|c|}
\hline ALTERNATIF & S+ & S- & C+ \\
\hline A5 & 0,6377664 & 0,843237 & 0,5693686 \\
\hline A6 & 0,6003546 & 0,792330 & 0,5689228 \\
\hline A9 & 0,6510897 & 0,812116 & 0,5550253 \\
\hline A1 & 0,6854497 & 0,836385 & 0,5495899 \\
\hline A10 & 0,6997990 & 0,802464 & 0,5341701 \\
\hline A7 & 0,7014981 & 0,798001 & 0,5321784 \\
\hline A4 & 0,8074162 & 0,782751 & 0,4922443 \\
\hline A2 & 0,7971359 & 0,764028 & 0,4893965 \\
\hline A3 & 0,7715401 & 0,572085 & 0,4257774 \\
\hline A8 & 0,9600845 & 0,497613 & 0,3413693 \\
\hline
\end{tabular}

Berdasarkan hasil yang diperoleh saat melakukan perhitungan yang telah dilakukan, sehingga kandidat yang memperoleh nilai akhir $>0,5$ tersebut akan direkomendasikan sebagai calon penerima bantuan KIP oleh Perguruan Tinggi Swasta (PTS). Hasil akhir dari perhitungan setelah dilakukan proses perangkingan ditampilkan pada tabel 19 berikut:
Tabel 19. Tabel Hasil Akhir

\begin{tabular}{|r|c|c|c|}
\hline \multicolumn{1}{|c|}{ NO } & KANDIDAT & $\begin{array}{c}\text { NILAI } \\
\text { AKHIR }\end{array}$ & KEPUTUSAN \\
\hline 1. & Mhs 5 & 0,5693686 & Rekomendasi \\
\hline 2. & Mhs 6 & 0,5689228 & Rekomendasi \\
\hline 3. & Mhs 9 & 0,5550253 & Rekomendasi \\
\hline 4. & Mhs 1 & 0,5495899 & Rekomendasi \\
\hline 5. & Mhs 10 & 0,5341701 & Rekomendasi \\
\hline 6. & Mhs 7 & 0,5321784 & Rekomendasi \\
\hline 7. & Mhs 4 & 0,4922443 & Tidak Rekomendasi \\
\hline 8. & Mhs 2 & 0,4893965 & Tidak Rekomendasi \\
\hline 9. & Mhs 3 & 0,4257774 & Tidak Rekomendasi \\
\hline 10 & Mhs 8 & 0,3413693 & Tidak Rekomendasi \\
\hline
\end{tabular}

\section{KESIMPULAN}

Berdasarkan pembahasan di atas, dapat disimpulkan sebagai berikut:

1. Bahwa Technique For Order Preference by Similarity to Ideal Solution (TOPSIS) dapat diterapkan pada pengambilan keputusan yang melibatkan banyak pihak. Proses pengambilan keputusan juga sangat bergantung pada kriteria preferensi yang dipilih.

2. Dapat membantu PTS dalam memecahkan masalah perhitungan dan menentukan kriteria agar lebih obyektif dalam pemilihan kandidat penerima bantuan KIP.

3. Penyelenggaraan KIP Kuliah pada PTS dapat menjadi salah satu ajang promosi terhadap calon mahasiswa yang memiliki keterbatasan ekonomi.

4. Untuk kesempurnaan metode yang digunakan pada penelitian ini, diharapkan agar dikombinasikan lagi dengan metode madm lainnya untuk dapat meningkatkan akurasi pemilihan alternatif.

\section{DATAR PUSTAKA}

[1]. Bhutia, P. W. \& Phipon, R., 2012. Application of AHP and TOPSIS Method for Supplier Selection Problem.OSR Journal of Engineering, 2(10),

[2]. Hwang, C.L.; Yoon, K, (1981) Multiple Attribute Decision Making Method: Methods and Applications New York: Springer-Verlag

[3]. L. A. Zadeh, "Fuzzy Sets As A Basis For A Theory Of PossibilitY,” p. 26.

[4]. Permendikbud No 10 Tahun 2020

[5]. Tzeng, G.-H. \& Huang, J.-J., 2011. Multiple Attribute Decision Making: methodsand applications. Boca Raton: CRC Press.

[6]. Undang Undang No 12 Tahun 2012

[7]. Undang Undang Dasar Tahun 1945 pasal 31, ayat (1).

[8]. www.wikipedia.org diakses pada bulan juli 2021

[9]. Yoon, K.P. and Hwang, C.L. 1995. Multiple Attribute Decision Making: An Introduction, Sage Publications, Thousand Oaks, CA. 